УДК 930.25

doi 10.17072/2219-3111-2019-1-165-174

\title{
«КРИЗИС РЕВОЛЮЦИИ И ЗАДАЧИ ПРОЛЕТАРИАТА» И ОСОБЕННОСТИ ИСТОЧНИКОВЕДЧЕСКОГО АНАЛИЗА ДОКУМЕНТОВ БОЛЬШЕВИКОВ-ЛЕНИНЦЕВ 1930-Х ГОДОВ ${ }^{1}$
}

\section{A. А. Фокин}

Челябинский государственный университет, 454001, Челябинск, ул. Братьев Кашириных, 129 Южно-Уральский государственный университет, 454084, Челябинск, пр. Победы, 162в aafokin@yandex.ru

\begin{abstract}
Публикуется один из документов, найденных в 2018 г. в Верхнеуральской тюрьме, написанных представителями левой оппозиции, находившимися там в заключении в 1930-е гг. Указанные документы составляют корпус текстов «Тетради Верхнеуральского политического изолятора», в котором выделяется подкорпус «Кризис революции и задачи пролетариата». В этих текстах большевики-ленинцы выразили собственный взгляд на ситуацию в СССР и предложили альтернативные модели развития страны. Публикуется первый из одиннадцати текстов «Кризиса революции и задач пролетариата», в котором авторы излагают теорию перманентной революции, созданную сторонниками Льва Троцкого, определяют сталинскую модель социализма как национал-социалистическую, отмечают, что поражение левой оппозиции означает поражение не только троцкистов, но и ленинской линии, что приводит к кризису революции и ставит перед пролетариатом новые задачи. Важным аспектом работы с найденными документами является их источниковедческий анализ. Современное источниковедение, с одной стороны, предоставляет универсальные инструменты для исследования текстов, с другой стороны, не уделяет достаточного внимания специфике политических документов XX в. Таким образом, в статье определяются ключевые пункты анализа документов «Кризиса революции и задач пролетариата», а также перспективы их дальнейшего источниковедческого изучения.
\end{abstract}

Ключевые слова: большевики-ленинцы, левая оппозиция, Верхнеуральский политический изолятор, источниковедение.

Поражение левой оппозиции в 1920-е гг., закрепленное решением XV съезда ВКП(б) о несовместимости принадлежности к «троцкистско-зиновьевскому блоку» с членством в партии, привело к тому, что многие сторонники Льва Троцкого, которого в 1929 г. выслали из страны, не только оказались исключены из партии, но и были помещены в политизоляторы. В советской историографии сформировалась точка зрения, которая затем стала господствующей: к концу 1927 г. деятельность троцкистов в СССР прекратилась, переместившись за границу. Так, с 1929 г. в Париже издавался «Бюллетень Оппозиции (большевиков-ленинцев)». Ряд современных исследователей оспаривают эту точку зрения как на всероссийском, так и на региональном материале и аргументированно показывают, что деятельность левой оппозиции продолжалась в стране нелегально, в том числе в местах заключения [Вrоиї, 1990; Гусев, 1996; Шабалин, 2003; Вакуленко, 2009]. Но до недавнего времени данные о деятельности левой оппозиции в СССР в 1930-е гг. были прежде всего косвенные: материалы в «Бюллетене Оппозиции», мемуары, например, книга известного югославского коммуниста Анте Цилига [Ciliga, 1977], который с 1930 по 1935 г. находился в различных политизоляторах. Можно сделать предположение о том, что ряд источников о деятельности левой оппозиции в подполье сохранился в ведомственных архивах, но большинство исследователей не имеют к ним доступа.

Обнаружение в 2018 г. в Верхнеуральской тюрьме документов начала 1930-х гг. дает историкам возможность анализировать тексты, созданные непосредственно большевиками-ленинцами в политическом изоляторе. Для удобства предлагается обозначить найденные тексты как «Тетради Верхнеуральского политического изолятора» (ТВПИ). Документы были созданы в 1932-1933 гг., возможно, ТВПИ являются частью более обширного фонда документов, но ранние тексты или не сохранились, или еще не обнаружены. Поскольку находка в Верхнеуральске была сделана случайно во время ремонта камеры, есть вероятность того, что будут найдены и другие тетради.

(C) Фокин A. A., 2019 
Обнаружение данных документов вызвало бурную реакцию СМИ, которые преподносили его как сенсацию и привлекали внимание читателей громкими заголовками в духе «Свержение Сталина готовилось в тюрьме Верхнеуральска». Интерес к находке проявило и профессиональное сообщество, которое в социальных сетях стало активно обсуждать новость. Поэтому я решил осуществить оцифровку ТВПИ, чтобы была возможность изучить, опубликовать и предоставить коллегам доступ к найденной информации. Поскольку объем ТВПИ довольно большой, нет возможности подготовить к печати весь комплекс источников. На данном этапе идет постепенная расшифровка текстов и их публикация. Первый текст из ТВПИ был напечатан в журнале «Аb Imperio» [Фашистский переворот, 2017]. Важной проблемой, которая сейчас стоит перед исследователями ТВПИ является неопределенный статус их хранения. В данный момент документы находятся в ГУФСИН ${ }^{2}$ по Челябинской области и руководство не определись с их судьбой. А поскольку эти материалы официально не имеют места хранения, это затрудняет доступ к ним и делает проблематичным оформление ссылок.

Описывая данный комплекс текстов, необходимо отметить, что из-за специфических условий хранения часть тетрадей оказалась сильно поврежденной, поэтому пока невозможно точно определить количество текстов. Предварительно можно говорить о 30-35 отдельных документах. Состояние 27 из них позволяет уверенно определить их и работать с ними. Можно выделить подкорпус текстов, который их авторы назвали «Кризис революции и задачи пролетариата» (КРЗП). Он включает в себя 11 тетрадей, 2 из которых утеряны, но их название и примерное содержание можно установить из перечня всех документов. Таким образом, в подкорпус «Кризис революции и задачи пролетариата» входят следующие тексты: I. Стратегическая линия пролетарской революции; II. Эволюция классовых отношений в ССCP; III. Мировое положение и Коминтерн; IV. Гос. хозяйство и перспективы его развития; V. Положение рабочего класса; VI. Сельское хозяйство; VII. Эволюция советского государства и опасность бонапартизма; VIII. Партия; IX. Тактика и задачи ленинской оппозиции; X. Программа практических предложений; XI. Заключение. Против оппортунизма! За революционную теорию и практику Маркса-Ленина!

Данный подкорпус текстов является центральным в «Тетрадях Верхнеуральского политического изолятора», поскольку содержит программу «большевиков-ленинцев», в которой они излагают собственный взгляд на основные аспекты политики в стране и мире. Этот факт показывает, что, даже находясь в заключении в 1932 г., представители левой оппозиции не считали свое положение обреченным и видели некоторые перспективы продолжения политической борьбы со сталинизмом.

Первичное исследование документов позволяют заключить, что почти все они являются самодельными «кодексами» (хотя присутствуют и тексты, написанные на отдельных листах). Для обложек использовались обложки печатных изданий. Так, для VI и VII выпусков «Кризиса революции и задач пролетариата» была взята обложка журнала «Коммунистический интернационал».Это свидетельствует о том, что заключённые имели доступ к печатным изданиям, могли получать информацию о событиях в стране и мире и использовать издания по своему усмотрению.

Хотя в части ТВПИ указаны авторы (их псевдонимы, что требует дополнительной работы по расшифровке),тексты КРЗП анонимны, поскольку являются продуктом коллективного творчества. Тем не менее можно предположить о значительном влиянии на тексты ТВПИ отдельных заключенных, например Виктора Эльцина, бывшего личным секретарем Льва Троцкого. Но, если даже в ходе исследования будет установлена роль отдельных личностей в создании КРЗП, важно понимать, что сами большевики-ленинцы Верхнеуральского политического изолятора расценивали документы не как отражение позиции отдельного человека, а как общую платформу.

Можно выдвинуть гипотезу о том, что создание ТВПИ в целом и КРЗП в частности преследовало две цели. Первая, явная, цель связана с тем, что представители большевиков-ленинцев критиковали сталинский вариант развития государства, считали его отступлением от ленинских принципов и рассматривали в широком плане как формирование несоциалистической системы внутри СССР. Таким образом, в ходе работы над текстами, в которых соединялись критика существующей системы и взгляд на решение основных политико-экономических вопросов, должна была быть создана альтернативная модель СССР. Сложно судить о том, в какой степени заключенные верили в то, что им удастся реализовать свои проекты и они смогут в 1930-е гг. противостоять сталинскому режиму. В связи с этим обнаруживается и вторая, скрытая, цель работы над КРЗП. Возможно, под- 
готовка текстов была важным инструментом сборки большевиков-ленинцев. Активное коллективное обсуждение проекта придавало дополнительный смысл их жизни в Верхнеуральском политическом изоляторе и позволяло заключенным поддерживать ощущение коллективного «мы».

При подготовке источника к публикации по возможности сохранены особенности текста. Например, в 1930-е гг. при письме не использовали Ђ и в источнике он тоже отсутствует; также сохранены исходные сокращения, подчеркивания и др. К сожалению, из-за плохой сохранности источника часть слов невозможно расшифровать, поэтому в тексте они обозначены как неразборчивые.

Надеюсь, что публикация документа из «Тетрадей Верхнеуральского политического изолятора» привлечет внимание исследователей и послужит стимулом к изучению левой оппозиции в 1930-е гг., что позволит скорректировать представления о политической истории большевиковленинцев.

\section{Примечания}

${ }^{1}$ Исследование поддержано РФФИ, проект 19-09-00517 «Антисталинская коммунистическая оппозиция в СССР в начале 1930-х годов».

${ }^{2}$ Автор благодарит за предоставленные документы ГУФСИН России по Челябинской области.. Автор благодарит за предоставленные документы ГУФСИН России по Челябинской области.

\section{Библиографический список}

Вакуленко А.А. Политическая публицистика коммунистической оппозиции: 1929-1941 гг.: Дис. ... канд.ист.наук. Тюмень, 2009. 202 с.

Гусев А.В. Троцкистская оппозиция в конце 20 -х - начале 30 -х годов: Дис. ... канд.ист.наук. М., 1996. $225 \mathrm{c}$.

Фашистский переворот в Германии («Большевик-ленинец» № 2 [12]. 1933 год) // Ab Imperio. 2017. № 4. С. 195-230.

Шабалин В.В. Пейзаж после битвы. Из истории левой оппозиции на Урале. Пермь: Б.и., 2003. $170 \mathrm{c}$.

Anté C. Dix ans au pays du mensonge déconcertant. Paris: Champ Libre, 1977. 563 p.

Brouï P. Party Opposition to Stalin (1930-1932) and the First Moscow Trial // Strong J. W. (Ed.). Essays on Revolutionary Culture and Stalinism. Slavica Publishers, 1990. P. 98-111.

Дата поступления рукописи в редакиию 24.07.2018

\section{"THE CRISIS OF THE REVOLUTION AND THE TASKS OF THE PROLETARIAT": SOURCE EVALUATION OF DOCUMENTS COM- POSED DURING THE 1930s BY THE BOLSHEVIK-LENINISTS}

\section{A. A. Fokin}

Chelyabinsk State University, South Ural State University, Pobedy ave., 162v, 454084, Chelyabinsk, Russia aafokin@yandex.ru

The paper examines a handwritten document composed in the 1930s by representatives of the Left Opposition in the Verkhneuralsk prison and found there in 2018. The text entitled "The Strategy of the Proletariat Revolution" is the first of the eleven documents grouped under the general title "The Crisis of the Revolution and the Tasks of the Proletariat". The existence of these documents is the conclusive proof of the Left Opposition's activities during their imprisonment. In the introductory paragraph, I provide a brief summary of the found texts and discuss the possibility of determining the authorship and the authors' goals. I argue that, by writing the documents, the authors pursued two goals. On the one hand, the Left Opposition criticised the Stalinist model of the Soviet Union and proposed an alternative version of the country's development. In their opinion, Stalin wrongly portrayed the idea of socialism, while the Left Opposition representatives were the advocates of the right Leninist tradition. On the other hand, an active group discussion brought the meaning to the authors' lives during their imprisonment and created an impression of unity with other prisoners. The found document consists of three parts, in which the authors outline the theory of permanent revolution typical for Leon Trostky's advocates. They also describe the Stalinist model of socialism as national socialism. Further, the authors note that the Left Opposition's defeat also means the Trotskyists' failure and 
the collapse of the Leninist party, which, in turn, leads to a crisis of revolution and sets new challenges for the proletariat.

Key words: Bolshevik-Leninists, left opposition, Verkhneuralsk political isolator, source study.

\title{
References
}

Brouï, P. (1990), "Party Opposition to Stalin (1930-1932) and the First Moscow Trial", in Essays on Revolutionary Culture and Stalinism, Slavica Publishers, Columbus, USA, pp. 98-111.

Ciliga, A. (1977), Dix ans au pays du mensongedéconcertant, Champ Libre, Paris, France, 563 p.

Gusev, A.V. (1996), Trotskistskaya oppozitsiya v kontse 20-kh - nachale 30-kh godov [The Trotskyite opposition in the late 20s - early 30s], PhD dissertation, Moscow State University, Moscow, Russia, 225 p.

Istochnikovedenie istorii SSSR: Uchebnik. 2-e izd. [Source study of the history of the USSR] (1981), Vysshaya shkola Moskvy, Moskva, Russia, 496 p.

Istochnikovedenie: Teoriya. Istoriya. Metod. Istochniki rossiyskoy istorii: Ucheb. Posobie [Source study: Theory. History. Method. Sources of Russian History] (1998), Rossiysk. gos. gumanit. un-t, Moscow, Russia, 702 p.

Istochnikovedenie: uchebnoe posobie [Source study] (2015), Izd. dom Vysshey shkoly ekonomiki, Moscow, Russia, 685 p.

Shabalin, V.V. (2003) Peyzazh posle bitvy. Iz istorii levoy oppozitsii na Urale [Landscape after the battle. From the history of the leftist opposition in the Urals], PGTU, Perm, Russia, $170 \mathrm{p}$.

Vakulenko, A.A. (2009) Politicheskaya publitsistika kommunisticheskoy oppozitsii: 1929-1941 gg. [Political publicism of the communist opposition: 1929-1941], PhD dissertation, Tyumen State University, Tyumen, Russia, 202 p.

\section{КРИЗИС РЕВОЛЮЦИИ ЗАДАЧИ ПРОЛЕТАРИАТА}

\author{
Раздел I \\ СТРАТЕГИЧЕСКАЯ ЛИНИЯ \\ ПРОЛЕТАРСКОЙ РЕВОЛЮЦИИ
}

\section{Содержание}

1. Введение

2. Гл.І. Теория перманентной революции и проблемы строительства в СССР

3. Гл.II. Национал- социализм и пролет. революция

4. Гл. III. Современный кризис революции и стратегические задачи пролетариата

\section{СТРАТЕГИЧЕСКАЯ ЛИНИЯ ПРОЛЕТАР. РЕВОЛЮЦИИ \\ ВВЕДЕНИЕ}

В октябрьском перевороте демократическая революция переплелась непосредственно с первой стадией социалистической революции.

Выработанная Лениным на 8 ом с'езде программа большевистской партии рассматривает октябрьский переворот как первый этап мировой революции, от которой ты не отделим. В этом положении нашей программы нашел свое выражение основной принцип перманентной революции: «Величайшая историческая проблема русской революции, необходимость решить задачи международные... проделав переход от революции как узко- национальной - к мировой» - от характеристики Лениным задач н/ peволюции целиком оправдала себя на всех дальнейших этапах ее развития. Все основные трудности и противоречия н/ революции опирались в противоречия между интернациональным характером революции и национальным характером соцстроительства внутри страны. Вот почему Ленин неустанно повторял, что: «наше спасение от всех этих трудностей во всеевропейской революции» и что « мы далеки от того, чтобы закончить даже переходный период от капитализма к социализму. Мы никогда не обольщаем себя надеждами на то, что сможем закончить его без помощи международного пролетариата» (Ленин). Этими ленинскими положениями, составляющими основу теории перманентной революции определяется стратегическая линия марксизма - большевизма. Ей противостоит теория социализма в одной стране, дающая национальное освящение совершенной революции отрывающая её от международной революции и являющаяся стратегической основой национал- социализма. 
Теория перманентной революции и проблемы

Социалистического строительства СССР

1) Основной исходный пункт теории перманентной революции выражен в следующих словах Ленина «поскольку крупная промышленность в мировом масштабе есть, поскольку бесспорно возможен непосредственный переход к социализму и никто не опровергнет этого факта» (Т.18, г.І, ст. 435)

Этим снимается вопрос о зрелости или не зрелости отдельных стран для социализма. Для победоносного перехода к социалистической революции в любой технически отсталой, крестьянской стране необходима только, чтобы пролетариат данной страны по социально-исторической своей роли был в состоянии встать во главе национально-демократической революции и опрокинуть власть буржуазии. Но из этого исходного положения вытекает тот факт, что победившая пролет. революц. в России является лишь звеном интернациональной цепи, и что при современном состоянии мирового хозяйства и международном разделении труда. Мы существуем в цепи капитал-государств, как звено мирового хозяйства и следовательно, - «правильная оценка п/революции возможна лишь с междунар. точки зрения» (Ленин)

2) Динамическое равновесие советского хозяйства нельзя рассматривать как равновесие замкнутого и самодовлеющего хозяйства. Экономика СССР развивается под давлением мирового хозяйства; она вошла в систему международного разделения труда и представляет собой очень своеобразную, но все же составную часть мирового рынка» которому мы подчиняемся (Примеч.позже исправлено на «подчинены») и от которого не оторваться» (Ленин). Внутри - хозяйственное равновесие поддерживается работой экспорта и импорта. Чем больше советское х- во вовлекается в систему международного разделения труда, тем прямее и непосредственнее такие элемента советского х-ва как цена и качество попадают в зависимость от соответствующих элементов мирового рынка. Одновременно советское х-во находится в непрерывной борьбе с мировой капиталистической системой ...[неразборчиво]связей с мировым рынком обостряет эту борьбу. В этих условиях силу нашего сопротивления экономическому и военнополитическому нажиму мирового капитала определяет тема нашего хозяйственного развития. Но в выборе темпов, мы не вольны. Он определяется с одной стороны материальными условиями самого производственного [неразборчиво], с другой необходимостью в конечном счёте догнать и перегнать передовые капиталистические страны, ибо и писала наша платформа: «при длительной борьбе непримиримо враждебных систем; капитализма и социализма исход определяется в последнем счетесоотношением их производительности труда, которое в условиях рынка измеряется через соотношение цен внутренних и мировых». Сохранить динамическую пропорциональность всего хозяйства в целом и в тоже время всемерно ускорить собственное развитие, обеспечив перевес социалистических элементов над капиталистическими, мы сможем лишь в том случае, если опираясь на преимущества планово-соц. Хоз-ва, умело воспользуемся ресурсами, вытекающими из условии мирового разделения труда.

3) Поскольку при наличии, связного мирового х-ва и мирового разделения труда ни одна отдельно взятая страна (даже самая передовая), не обладает разносторонне развитой крупной машинной индустрией, способной обеспечить построение социализма, в замкнутых национальных рамках (такая промышленность, обеспечивающая построение социализма существует лишь в мировом масштабе), - поскольку пролетариат вынужден, в интересах повышения производительности труда, одновременно с усилением внешне-торговых связей, допускать в известных пределах, развитие капитализма внутри страны (концессий, смешанные ... [неразборчиво],внутр. рынок). От сюда -же вырастает и НЭП как такая форма экономической связи, между крупной промышленностью и массой разрозненных мелких с/х производителей, которая диктуется нам всей системой современного мирового хозяйства.

Таким образом оказывается, что: «наш социальный строй основанный только на борьбе социализма и капитализма, но в известных пределах и на их сотрудничестве» (Троцкий). В этих условиях основная задача состоит в том, чтобы: «направить неизбежное развитие (до известной степени и на известный срок) капитализма в русло гос-капитализма..., обеспечить превращение в не далеком будущем госкапитализма в социализм... усилить государственно-упорядоченные отношения в противовес мелкобуржуазным анархическим» (Ленин), т.е. другими словами: подчинить м-б. стихию гос-учету и контролю и подготовить условия для индуст. и коллектив, на основе электрификации, ибо: «если не электрификация, все равно неизбежный возврат к капитализму». (Ленин)

4) Все основные хоз. процессы в СССР не ...[неразборчиво]в связь с ... [оборван край страницы]«и подпадают в той или иной степени, под действие законов, управляющих капитал. развитием, в том числе и сменой кон юктур (Троцкий). Этим создается своеобразное переплетение и взаимная связь внутрен. и внешн. противоречий. Внутренние противоречия неразрывно связываются с внешними в один узел. Преодоление первых невозможно без разрешения вторых. Невозможность построения самодовлеющего соц. $\mathrm{x}$-ва воспроизводит, внутренние и внешние противоречия соц. строительств на каждой новой стадии во все большем об’еме и со все большой глубиной. Таким образом, все противоречия развития СССР в конечном счете ведут к противоречиям между изолированным раб. государств. и капиталистическим миром, его окружающим. Полное преодоление всех этих противоречий возможно только на путях мировой революции. 
5) Социалистическое строительство СССР протекает на основе непрерывной и обостренной классовой борьбы в национальном и интернациональном масштабе. Пролетарская революция, в отличие от всех других революций стремится не к увековечиванию господством какого нибудь одного класса, а к уничтожению всех классов. Представляя собой непрерывный процесс, она не может задерживаться на формальном этапе, не давая обществу найти своего равновесия, - она проходит фазу спада, должна подготовлять в тоже время элементы будущего подема на более высокой основе, чем тот, который был достигнут на предыдущем под`еме. Все развитие всецело происходит в непрерывных столкновениях различных классовых групп, перестраивающегося общества и в фазе бесконечной борьбы и происходит переделка всех социальных отношений. «Пока остаются рабочие и крестьяне до тех пор социализм остается неосуществимым и на практике и на каждом шагу происходит непримиримая борьба». (Ленин) Однако, методы и формы этой борьбы пролетариата с крестьянством должны быть иные, чем те, которые пролетариат применял и капиталистам и помещикам.

Они приобретают одновременно и форму «смычки» соглашение этих классов на основе гегемонии пролетариата. Соглашение это достигается известными уступками крестьянству: «в определении способов проведения социалистических преобразований» (прогр. ВКП) в пределах курса на уничтожение классов и в целях укрепления власти пролетариата. Путь преодоления крестьянства «последнего капиталистического класса», не есть путь административной его ...[неразборчиво] методами к апроприации, а путь [неразборчиво]влияния крупной индустрии на с/х.Соглашение с крестьянством должно явится одной из мер, направленных к уничтожению классов, т.е. средством восстановления и дальнейшего, мощного развития крупной промышленности и соц. переделки самого крестьянства. «Но эта задача (полная ликвидация противоречия между городом и деревней) - одна из основных задачсоциализма, - потребовало бы в свою очередь, использования ресурсов мирового хозяйства». (Троцкий, «Проблемы развития СССР») Разрешить эту задачу полностью и до конца возможно лишь в рамках мировой промышленности, т. е. после победы рабочих передовых стран. До этой победы: «главным вопросом для нас остается правильное установление отношении между пролетариатом и крестьянством, правильное с точки зрения уничтожения классов». (Ленин)

6) Поскольку капиталистический строй господствует на мировой арене, тысячи нитей связывают мелкое товарное хозяйство, рождающее капитализм ежечасно в массовом масштабе, с мировым капитализмом. Поэтому развитие классовой борьбы внутри страны тесно связано и обусловлено с общим ходом международной классовой борьбы. Вопрос: «Кто кого», даже только с точки зрения внутренних взаимоотношений, не решается цифровым соотношением частного и государ. х-ва внутри СССР. Он решается соотношением капитализма и социализма на мировой арене. Если бы капиталистический строй оказался в состоянии продержаться еще в течений целой эпохи, то капиталистически-фермерские тенденции неизбежно, - при этих условиях увлекли бы за собой середняка, парализуя воздействие пролетариата на деревню и создавая политическое препятствие соц. строительству. Все это привело бы к разрыву взаимоотношений пролетариата и крестьянства и сделало бы неизбежной гибель диктатуры пролетариата. Поэтому, вслед за т. Троцким, мы утверждаем, что: «пролетарская революция может удержаться в национальных рамках только на время... В изолированной стране параллельно с её успехами растут неизбежно противоречия, порождаемые как внутри, так и во вне её зоны. Если бы эта изоляция продолжалась, пролетарское гос-во должно было бы погибнуть став жертвой насаждающих его противоречий. Его спасение единственно в победе пролетариата передовых стран. Но с точки зрения соотношения классовых сил на мировой арене у нас нет никаких оснований считать победу пролетариата других стран делом далекого будущего.

«Свержение мировой буржуазии в революционной борьбе есть много более реальная и непосредственная задача, чем догнать и перегнать мировое хозяйство, не переступая за пределы СССР (Тр.) Считать на данном историческом этапе гибель диктатуры пролетариата неизбежной, или даже наиболее вероятной могут только те кто: «кто верит в непоколебимость мирового капитализма или в его долговечность. Левая оппозиция ничего общего не имеет с такого рода капиталистическим оптимизмом» (Троцкий). Поэтому Лен-оппозиция не считает об ективно неизбежным разрыв с крестьянством на данном историческом этапе. Такой разрыв, - а следовательно и гибель диктатуры пр-та на данном историческом этапе может явится только в результате неправильной политике руководства.

7) Отдавая себе ясный отчет в том, что пролетарская диктатура может удержатся в национальных рамках только на время и что поэтому основной задачей является превращение диктатуры пр-та из национальной в интернациональную, ленинская оппозиция никогда не игнорировала необходимости установления соглашения с середнякам, ни на минуту не ослабляя борьбы с кулаком и прочно опираясь только на бедноту - «задача внутри страны сводится к тому, чтобы укрепляя себя правильной классовой политикой, правильным взаимоотношением раб. класса и крестьянства, как можно дальше продолжаться вперед по пути соц. строительства. Внутренние ресурсы СССР велики и делают его вполне вероятным, используя в этих условиях мировой капитал-рынок, мы свой основной историч. расчет связываем с дальнейшим годом [неразборчиво]мировой пролетарской политики» - писала платформа в 1927 г. 
Этапы развития революции в СССР, в конечном итоге определяются изгибами в развитии мировой революций, которую лен-оппозиция всегда рассматривала как единый процесс, «подчинение интересов пролет. борьбы в одной стране, интересам этой борьбы во всемирном масштабе» - таков основной Ленинский лозунг « определяющий стратегические задачи социалистического пролетариата СССР и являющийся одновременно одним из основных положений теорий перманентной революций.

\section{Глава II ая}

Национал-социализм и пролетарская революция

1) Возникновение новой разновидности национал-социализма в России имеет свои идейные истоки в правом большевизме периода 1905-17 гг. Расходясь с меньшевиками в вопросе об оценке роли буржуазии в демокр. революции, правый большевизм в 1905 г. в тоже время решительно выступил против захвата власти пролетариата и ограничивал нашу революцию бур- демократическими вещами. В 1917 г (в период февраля-марта все без исключения теперешние описаны, а после приезда Ленина - каменев, Рыков, затем Зиновьев и де/правые большевики вели неустанно борьбу против Ленина, окончательно скатившись, при этом на позицию левого крыла радикальной м/б. демократии, что заставило Ленина, даже поставить вопросом: «место ли правому большевизму в нашей партии?» (Ленин сб.№ 11)

2) Идейными преемниками правого большевизма, наряду с современными правыми, является и сталинский центризм. В Китае, Индии, Испании и во всех колониальных и отсталых странах, а в последнее время и в Японии, центризм борется против стратегической линии на пролетарскую революцию и диктатуру пролетариата, как основного метода разрушения задач демократич. революции; проповедует, ставший реакционным лозунг, демократ. диктатуры пролетариата и крестьянства, дополненной теорией и практикой двухсоставной партии; отрывает демократическую революц. в колониях от растущей международной революции и рассматривает их через позиции национальной революции, в то время как 쓰 деле является звеном интернациональной цепи и не представляет собой самоцели. Этим самым сталинский центризм растворяет пролетариат в мелкой буржуазии и подчиняет его национальной буржуазии.

3) Теория социализма в одной стране, провозглашена и центристами в 1924 г. и построена на не понимании противоречии между интернациональным характером п/революции и национальным характером соц. строительства в СССР - есть стратегическая линия национал-социализма. В основе этой теории лежит взгляд на крестьянство, как на ...[неразборчиво]обладающей ... [неразборчиво]социалистическими качествами, т.е. стремлением: «врастать в социализм» - таким образом, вне зависимости от судьбы пролетариата других стран - преодоление внутр. противоречий в стране пролет. диктатуры и построение национал-социалист. Общества - согласно теории национал- социалистов обеспечено самим фактом соглашения с крестьянством. Единственным препятствием для построения национального социализма, с точки зрения этой теорий, может явится лишь интервенция.

Таким образом, если в 1905 г. правые большевики не допускали мысли о завоевании власти пролетариатом в России, раньше чем в Запад. Европе, а в 1917 г. они пропагандировали демократ. Революцию в России, в себе и для себя и отвергали мысль в диктатуре пролетариата, то идейные их преемники - современные правые и центрист, - начиная с 1924 г. рассматривают завоевание власти пе- том, в национальных рамках, не как начальный акт, а как конечный акт революциии провозгласили вполне возможным построение в СССР изолированного социалистического общества, в себе и для себя. Международная революция перестала быть для них необходимым условием победы, а стала в их глазах лишь благоприятным обстоятельством.

4) Основными чертами современного национал-социализма являются:

a) ограничение революции национальными рамками разрыв с пролетарским интернационализмом, требующим: «подчинения интересов борьбы в одной стране, интересам этой борьбы во всемирном масштабе» (Ленин);

б) отрыв внутренних противоречий от противоречий мирового хозяйства и непонимание того, что успехи соц. строительства растут вместе с его противоречиями;

в) отрицание положения Ленина, что мы: «существуем в цепи капиталист. госуд. как звено мирового хозяйства» и в связи с этим;2) курс на независимость от мирового хозяйства и на создание замкнутого самодовлеющего национального хоз-ва.

Разрыв с Лениным в этих маргинальных вопросах привел социализм к полному перевооружению, как в вопросах оценки движущих сил н/революции, которую они перестали рассматривать как звено международной революции, так и в отношении оценки среднего крестьянства, которое они вопреки Ленину, перестали рассматривать как: «последний капиталистический класс и в стране»

5) Национал-социализм в полном соответствии с теорией социализма в одной стране, рассматривает НЭП как такой исторический этап, который непосредственно, на основе сотрудничества с крестьянством, создает условия для полного построения социалистического общества в одной стране вне зависимости от судьбы пролетариата других стран. В начале кооперирование снабженически-бытовых функций крестьянских хозяйств теперь сплошная коллективизация и с/артель на основе обобществления крестьянского инвентаря -об 'являются достаточным условием для преодоления внутренних противоречий и 
врастания крестьянства в социализм. Национал-социалистическая тактика НЭПа находится в кричащем противоречии, со стратегической линией пролетарской революции и целиком подчинена стратегической линии национал-социализма - теории социализма в одной стране. Для Ленина НЭП всегда был лиш этапом на пути к международной революции, лишь приспособлением к темпу её развития. Ленинская тактика НЭПа заключалась в том, чтобы рядом медленных и осторожных, осадных действий подготовить, а затем и начать наступление внутри страны, памятуя о том, что: «крепость международного Порт-Артура будет сражена, ибо зреют силы во всех странах, которые ее сразят». (Ленин)

Переход в наступление в то же время не отменяет НЭП и его методы, а лишь видоизменяет формы отношений с крестьянством, поскольку он означает усиление борьбы с крестьянской буржуазией и внедрение коллективизации и совхозов - темп роста, которых определяется идеальным весом крупной промышленности, уровнем техники и масштабом наших связей с мировым хозяйством. Поскольку внутренние, хозяйственные процессы вырабатывают свое сложное политическое отражение, все основные эконом. Проблемы НЭПа являются прежде всего сложнейшими политическими проблемами от решения которых зависит судьба рабочего государства. Национал-социалисты игнорируют это политическое содержание проблем НЭПа.

6) Национал-социализм в России, ставший орудием общественно-политической реакции против социалистических тенденций октября, прошел два периода в своем развитии. В условиях относительного равновесия, в экономике и в политике н/ страны, когда основные противоречия революции ещё: «...думали» в плане т.н. «восстановительного периода». Курс национал- социализма нашел свое тактическое выражение в политике соглашения с кулаком и о приспособлении развития гос. хозяйства к нуждам и потребностям крестьянской буржуазии. Кооперация, как голая организационная форма была объявлена, столбовой дорогой к социализму. Борьба против теории перманентной революции и «троцкизма» была идеологическим знаменем, под которым совершалась мобилизация мелк. бурж. элементов и подготовлялся натиск на социалистическое завоевание октябрьской революции. Выставляя против оппозиции: «идею середняка», как высшего критерия политики национал- социализма не только сходил этим с пролетарских позиции, но и на деле подрывал пролетарский союз с середняком. Политика национал- социализма сводилась к тому, что в интересах союза с «середняком» (который на деле для национал-социал. оказывался синонимом кулака), он об`ективно подрывал гегемонию пролетариата, в то время, как Леноппозиция неустанно подчеркивала, что союз с середняком подчинен условию сокращения и укрепления гегемонии пролетар.

7) Второй период развития национал-социализма начинается с того момента, когда страна вышла из относительного равновесия и все подспудные силы, созревшие в прошлый период под покровом правой политике вышли наружу и обнажив основные противоречия н/революции обнаружили полное банкротство право- центристского курса.

Будучи не способна перейти на стратегическую линию пролетариата и непосредственно опереться на пролетарский авангард, а через него на широкие слои рабочих и деревенской бедности, не решаясь в тоже время на крутой поворот в право из страха перед начавший проявляться в 1928 г. сопротивления пролетариата, центристское крыло национал-социализма попыталось: « приспособится к пролетариату, однако без отказа от принципиальных основ своей политики и главным образом от концепции её всемогущества» (Троцкий). Это нашло свое выражение в попытке разрешить все противоречия, коротким ударом в нац-рамках , но на путях ультра-левой авантюры.

Сущность этой авантюры состоит: в политике авантюрных темпов индустриализации, в отмене НЭПа, в административной ликвидации классов в деревне и сплошной кол-ции как методов построения национал- социалистического общества в 4 года. Это поставило всю экономическую политику над реальными ресурсами и реальными классовыми отношениями.

В данном случае мы имеем дело с политикой, в основе которой лежит все та же старая теория социализма в одной стране, переключенная на третью скорость; курс на уничтожение классов в рамках замкнутого, самодовлеющего национального хозяйства. Загнав все противоречия современной деревни в колхоз, где они воспроизводятся на новой основе, отрицая дифференциацию в колхозах и об явив колхозы априорно соц-предприятиями. Сталинский центризм прикрывает в колхозах капит.-фермерские тенденции и отдает бедняка и батрака в жертву и эксплуатацию зажиточному колхознику.

Потеряв опору в кулаке и не найдя в рабочем классе, Сталинский центризм пытается создать себе опору в колхозном середняке, который согласно решениям XVIс'езда должен стать «опорой советской власти в деревне» и врастать в социализм на экономической базе мел-бурж. Хозяйства, административно-об единенного на основе обобществления крестьянского инвентаря.

«Бюрократическое форсирование темпов индустрии и коллективизации, опирающиеся на ложную теоретическую установку, означает бесшабашное нагромождение диспропорции и противоречии, особенно по линии взаимоотношения с мировым хозяйством» (Троцкий), с одной стороны, и по линии взаимоотношения города с деревней - с другой. В результате всей политики центризма, мы имеем обостре- 
ние отношений между государством и пролетариатом - пролетариатом и крестьянством, при одновременном возвышении бюрократии над классами и росте всеобщего недовольства.

8) Стратегическая линия национал- социализма, проверенная на опыте событий, обнаружила свою полную несостоятельность, поставив страну пролетарской диктатуры перед угрозой гибели, она в то же время является тормозом революции в отсталых, колониальных странах - губит и дезорганизует комитерн - парализуя коммунистическое движение во всем мире: «Международная левая оппозиция отвергает и категорически осуждает, созданную ...[неразборчиво] в 1924 г. теорию социализма в одной стране, как худшую реакцию против марксизма и основной продукт термидорианской идеологии непримиримая борьба со сталинизмом ( или национал- социализмом) нашедшее свое выражение в программе К. И. есть необходимое условие правильной революционной стратегии, как в вопросах международной классовой борьбы, так и в области хозяйственных задач СССР» (Троцкий).

\section{Глава III тья}

Современный кризис революции и стратегические задачи пролетариата.

1) В основе всех потрясений советской системы лежат следующие важнейшие переплетающиеся между собой исторические противоречия: «а) наследие капиталистических и докапиталистических противоречий старой царской буржуазной России, в первую очередь противоречия между городом и деревней; б) противоречие между общей культурной отсталостью и диалектически выросшим из этой отсталости задачами социалистического преобразования; в) противоречие между рабочим государством и капиталистическим окружением, в частности, между монополией внешней торговли и мировым рынком» (Троцкий). Все, эти противоречия, которые отнюдь и носят кратковременного и эпизодического характера, развертывались за последние 9 лет в условиях, созданных неправильной политикой руководства и тогдашними поражениями мирового пролетариата - начиная с 1923 г.

Общая культурная отсталость н/страны, при господстве мелкого производства в с/х создало глубокое противоречие между материальной базой и социально-политической надстройкой пролетарской диктатуры. На этой основе возводился, укрепился и обнаружил себя вполне бюрократизм: «как надстройка над распыленностью и придавленностью мелкого производителя» (Ленин), некультурностью широких рабочих масс, с одной стороны и как орудие борьбы против пролетариата, социалистических тенденции н/революции со стороны прошлого слоя государственных чиновников, представляющих собой осколки развитых господствующих ранее классов, являющихся мел.- бурж. а бюрократическоверхушечные элементы ВКП подпавшие в той или иной степени под влияние буржуазных элементов госапарата - поднялись на волне общественно-политической реакции и руководству партией и страной. В то-же время: « сов. бюрократия, представляющая собой ... [неразборчиво]верхнего слоя победоносного пролетариата с широкими слоями свергнутых классов, включат в себе ... [неразборчиво]агентуру мирового капитала» (Троцкий).

Теория социализма в одной стране идет на встречу социальным потребностям советской бюрократии, становящейся все более консервативной в своих стремлениях к национальному режиму и требующей окончательного освящения совершившейся революции (обеспечивающей бюрократии привилегированное положение), как якобы достаточной для мирного построения социализма.

Между творческими силами революции и бюрократией, господствует глубокий антагонизм. Неправильная политика центристской бюрократии, расходящаяся с историческими интересами рабочего класса, сама в свою очередь давно уже стала одним из главнейших источников роста бюрократизма. Воспользовавшихся неблагоприятным для пролетариата соотношением сил, центр. бюрократ. разгромила лен. ...[неразборчиво]партии, ликвидировала самую как самостоятельную организацию пролетарского авангарда, установила полит. и эконом. гнет над пролетариатом, ликвидировала профсоюзы как органы защиты интересов рабочих и как школу коммунизма, установила плебисцитарно - бонапартистский режим в партии, союзах, советах; усилив тем самым элементы двоевластия и касаясь в своей политике между оппортунизмом и авантюризмом, центрическое руководство привело страну к острому социальноэкономическому кризису и глубоким политическим потрясениям.

2) Выход из кризиса революции, созданного 9 летним господством парт. и сов. бюрократии в условиях общественно- политич. реакции, может быть лишь двух направлениях:1) либо буржуазная реставрация, через открытый насильственный контр.- револ. переворот; 2)либо восстановление пролет. диктатуры в полном объ еме, через глубокую реформу партии, союзов, советов. Борьба за этот второй путь составляет полит. содержание всей борьбы Ленинск. оппозиции - как Русского отряда между народной левой оппозиции.

3) Основной задачей пролетариата в экономической области является провести плановое отступление с позиции авантюризма в промышленности и с/х. Это отступление должно преследовать следующие задачи: 1) создание реальных хоз. планов, обеспечивающих постоянный рост х-ва на основе динамического равновесия; 2) восстановление доверия крестьянства к пролетариату и его государству(смычка); 3) такую перегруппировку сил в городе и деревне, которая создала бы условия для буду- 
щего наступления. Только при выполнении этих задач может пролетариат укрепить свою диктатуру и удержать пути к социализму до победы пролетариата других стран.

4) Плановое отступление с позиций авантюризма предполагает так-же отступление в сфере отношений между городом и деревней, к методам рынка, ограниченного жестким и растущим воздействием планового регулирования. Но такое отступление к методам рынка еще не разрешает проблемы, отношения с середняком в полит. области. Благодаря гибельной политике руководства доверие крестьянства, к результата и социалист. работы пр-та, оказалось подорванным. Согласится ликрестьянин середняк после того, что проделало с ним центр. Руководство за последние годы, заключить на почве НЭПа соглашение с рабочим классом,- или середняк не удовлетворится: «восстановление НЭПа» и потребует НЭП НЭПа и полит. гарантии - предугадать невозможно. Это покажет практика, опыт самого отступления, это будет зависеть в первую очередь от силы самого раб. класса в борьбе с бонапартист. контр-револ. которая будет стремиться вырвать из под его влияния средняцко-бедняцкие массы деревни.

Беря на себя инициативу отступления от авантюризма лен. оппозиция еще раз повторяет в след за Лениным его слова, которые должны быть положены в основу наших взаимоотношении с крестьянством: «Мы открыто, честно, без всякого обмана крестьянам заявляем: для того, чтобы держать путь к социализму. Мы Вам, товарищи крестьяне, сделаем целый ряд уступок, но только в таких-то пределах и в какой-то мере и конечно, сами будем судить, какая эта мера и какие пределы. Вот как стоит вопрос в отношениях между пролетариатом и крестьянстом, т.е. или крестьянство должно идти с нами на соглашение и мы делаем ему экономические уступки, или борьба»(Ленин)

5) Под давлением противоречий и трудностей, обостренных современной политикой, центр. руководство вынуждено будет начать стихийное отступление с позиций авантюризма. Но это отступление, при господстве центризма, неизбежно сдвинет всю политику в сторону политического НЭПа, т.е. передаст инициативу в руки термидорианско-бонапарт. элементов ВКП, которые уже сейчас вынашивают план бонапар. соглашения с крестьянством и мировым капиталом.

Для того, чтобы перерезать путь к отступлению на рельсы: «политического НЭПа», лен. оппозиция ведет непримиримую борьбу против правящей фракции центризма и выдвигает определённую программутребований и лозунгов, обеспечивающих выход из современного кризиса революции на пролетарских путях.

6) Ныне, как в период составления н/платформы: «в стране существуют две исключающих друг друга позиции, одна позиция пролетариата, строящего социализм, другая позиция буржуазии, стремящаяся вернуть развитие на капиталистический путь.

Руководящая фракция Стал. центризма, колеблясь между двумя этими позициями ... [неразборчиво] в блоке с Беседовскими: «на два фронта», а на деле главным образом с лен. оппозиц. - приводит к тому, что соотношение сил все больше складывается в сторону термид-бонапартистских сил.

Лен. же оппозиц. Является единственным представителем позиции пролетариата. В тяжелых условиях она продолжает отстаивать стратегическую линию марксизма-большевизма против националсоциализма и каждый шаг нашей революции она рассматривает под углом зрения развития междунар. революции, связывая с ней и только с ней свой основной исторический расчет. 